\title{
Is quantitative magnetic resonance imaging valuable in the assessment of trabecular bone structure in osteoporosis?
}

\author{
Osteoporozda trabeküler kemik yapısının değerlendirilmesinde \\ niceliksel manyetik rezonans görüntüleme değerli midir?
}

\author{
Nil Tokgöz, M.D., ${ }^{1}$ Mualla Akdeniz, M.D., ${ }^{1}$ Murat Uçar, M.D., ${ }^{1}$ Koray Kılıç, M.D., ${ }^{1}$, Azim Çelik, M.D. ${ }^{2}$ \\ 'Department of Radiology, Medical Faculty of Gazi University, Ankara, Turkey \\ ${ }^{2} \mathrm{GE}$ Medical Systems, İstanbul, Turkey
}

Objectives: This study aims to evaluate the value of quantitative magnetic resonance imaging in the assessment of bone trabeculae in osteoporosis by comparing the results with dual-energy X-ray (DXA) absorptiometry.

Patients and methods: The study consisted of 85 postmenopausal women (mean age 57.2 years; range 43 to 83 years) underwent both DXA absorptiometry and lumbar quantitative magnetic resonance imaging. $T_{2}$ and $T_{2} *$ values were calculated by magnetic resonance imaging and the results were compared with bone mineral density.

Results: According to bone mineral density t-scores; there were 32 normal, 30 osteopenic, and 23 osteoporotic patients. $\mathrm{T}_{2}$ values of L1- L4 were different in normal with osteoporotic, and the osteopenic with osteoporotic groups. There were increased $\mathrm{T}_{2}$ values with reducing t-scores. Comparing the normal and osteopenic groups, no statistical difference was found in $T_{2}$ measurements of lumbar vertebrae, except $L 4$. $\mathrm{T}_{2}$ * values of L1-L4 vertebrae were not statistically different between the study groups.

Conclusion: $\mathrm{T}_{2}$ measurements of lumbar vertebra on quantitative magnetic resonance imaging may be useful in evaluation of bone trabeculae in osteoporosis, and may also be helpful in differentiation of osteoporotic from normal, and osteopenic from osteoporotic patients.

Key words: Lumbar vertebrae; magnetic resonance imaging; osteoporosis; photon absorptiometry.

Osteoporosis is a metabolic bone disease characterized by both decreased bone mass and deterioration of bone microarchitecture, with an increased risk of fracture in weakened bone. ${ }^{[1,2]}$ The evaluation of bone quality and quantity is very important in the assessment of fracture
Amaç: Çalışmada çift enerjili X-ışını (DXA) absorpsiyometri ile sonuçlar karşılaştırılarak osteoporozda kemik trabeküllerinin değerlendirilmesinde niceliksel manyetik rezonans görüntülemenin değeri ortaya konuldu.

Hastalar ve yöntemler: Çalışmaya DXA absorpsiyometri ve niceliksel manyetik rezonans görüntüleme incelemeleri yap1lan 85 menopoz sonrası kadın (ort. yaş 57.2 yıl; dağılım 43-83 y1l) dahil edildi. Manyetik rezonans görüntülemede $T_{2}$ ve $T_{2}{ }^{*}$ değerleri ölçüldü ve sonuçları kemik mineral yoğunluğu ile karşılaştırıldı.

Bulgular: Kemik mineral yoğunluğu t-skorlarına göre; 32 normal, 30 osteopenik ve 23 osteoporotik hasta bulunmaktayd. L1-L4 vertebra $T_{2}$ ölçümleri normal ve osteoporotik ile osteopenik ve osteoporotik gruplar arasında farklı bulundu. T-skoru azaldıkça $T_{2}$ değerinde artış vardı. Normal ve osteopenik gruplar karşılaştırıldığında; $\mathrm{L} 4$ vertebra dışında, $\mathrm{T}_{2}$ ölçümlerinde istatistiksel fark bulunmadi. L1-L4 vertebra $T_{2}{ }^{*}$ ölçümleri çalışma grupları arasında istatistiksel olarak farklı değildi.

Sonuç: Niceliksel manyetik rezonans görüntülemede lomber $\mathrm{T}_{2}$ ölçümleri osteoporozda kemik trabeküllerinin değerlendirilmesinde yararlı olabilmekte ve normal hasta ile osteoporotik ve osteopenik ile osteoporotik hastaları ayırt etmede yardımcı olacağı düşünülmektedir.

Anahtar sözcükler: Lumbar vertebra; manyetik rezonans görüntüleme; osteoporoz; foton absorpsiyometri.

risk and effectiveness of treatment in osteoporotic patients. ${ }^{[3]}$

The World Health Organization (WHO) recommends the measurement of bone mineral density (BMD) with dual-energy X-ray absorptiometry (DXA) to quantify

- Received: November 26, 2012 Accepted: January 30, 2013

- Correspondence: Nil Tokgöz, M.D. Gazi Üniversitesi Tıp Fakültesi Radyoloji Anabilim Dalı, 06510 Beşevler, Ankara, Turkey Tel: +90312 - 2025163 Fax: +90312-2121940 e-mail: nil.tokgoz@gazi.edu.tr 
osteoporosis. ${ }^{[4]}$ Dual-energy $\mathrm{X}$-ray absorptiometry is the most commonly used technique in the diagnosis and follow-up of the disease. ${ }^{[4]}$ Although an inverse relationship was found between BMD and fracture risk, there are studies demonstrating that BMD is not a satisfactory predictor because deterioration in bone microarchitecture is also an important causative factor. ${ }^{[2,5,6]}$

In an effort to evaluate trabecular bone structure, magnetic resonance imaging (MRI) techniques developed. Quantitative MRI (QMRI) with different measurement parameters has been proposed as a useful method in the evaluation of trabecular bony network. $\cdot^{[7,8]}$

The purpose of our study was to evaluate the value of $T_{2}$ and $T_{2}{ }^{*}$ measurements of lumbar vertebrae on QMRI in osteoporosis by comparing the results with DXA.

\section{PATIENTS AND METHODS}

Our institutional review board approved the study. Between April 2010 and August 2011, 118 postmenopausal women (at least one year since menopause) referred to us for lumbar MRI and who also had BMD data obtained on a DXA scanner in the last three months were included in the study. Informed consent was obtained from all patients following full explanation of the examination. Patients with MRI contraindications and history of disease or medications affecting bone metabolism such as malignancy, metabolic bone diseases, radiation therapy or chemotherapy were excluded from the study. The final study group therefore involved 85 postmenopausal women with a mean age of 57.2 years (age range, 43 to 83 years).

As body mass index (BMI) may affect the BMD data, heights and weights of the patients were measured, and BMI was calculated for each patient.

\section{Bone mineral density measurements}

Bone mineral density data were obtained on a DXA scanner (GE Medical Systems DPX Lunar). The L1-L4 vertebrae were scanned and measured in the anteroposterior direction. The patients were grouped as "normal," "osteopenic" and "osteoporotic" according to $\mathrm{t}$-scores described by the WHO. The $\mathrm{t}$-scores above -1 were considered normal, between -1 to -2.5 were considered osteopenic, and less than -2.5 were considered osteoporotic.

\section{Magnetic resonance imaging technique}

All MRI was performed by a 1.5 Tesla unit (Signa Excite 1.5T, GE Medical Systems, Milwaukee,
WI, USA). Following routine lumbar MRI, QMRI protocol for indirect assessment of bone trabeculae by measuring $\mathrm{T}_{2}$ and $\mathrm{T}_{2}{ }^{*}$ signal was obtained. In the QMRI protocol, sagittal fast spin echo and multiphase gradient echo sequences were obtained for $\mathrm{T}_{2}$ and $\mathrm{T}_{2}{ }^{*}$ measurements, respectively. The measurements were performed from the central portions of the L1-L4 vertebral body on mid-sagittal images by one radiologist blinded to DXA results. The mean signal intensity of the region of interest (ROI) was noted for each vertebra (Figures 1a, b).

\section{Statistical analyses}

Statistical analyses were performed using the SPSS (SPSS Inc., Chicago, Illinois, USA) for Windows version 15.0 software program. The variables were investigated using the Shapiro-Wilk test to determine whether they were normally distributed or not. Descriptive analyses for the variables in each group were presented by using means and standard deviations. One-way ANOVA and Kruskal-Wallis tests were used to compare the ages, BMI, and mean ROI values among the groups. When an overall significance was observed, pairwise post-hoc Tukey's test was used. $P$ values of less than 0.05 were considered to have statistically significant difference. The correlations between variables were also analyzed with the Pearson test.

\section{RESULTS}

Of a total of 85 patients, the patients grouped according to t-score values were 32 normal, 30 osteopenic and 23 osteoporotic. According to t-score values, there was a statistical difference between the ages of the normal and osteoporotic groups $(p<0.05)$. The BMI values showed no statistically significant differences between the groups $(p>0.05)$. The demographic features of the patients are summarized in Table I.

$\mathrm{T}_{2}$ measurements obtained from L1-L4 vertebrae showed statistically significant differences comparing normal with osteoporotic, and osteopenic with osteoporotic groups. In these groups, it was found that $\mathrm{T}_{2}$ measurements increased with reducing t-score values. Comparing normal and osteopenic groups, there was no statistically significant difference in $T_{2}$ measurement of lumbar vertebrae, except L4. $T_{2}$ measurements of the study groups are shown in Table II.

$\mathrm{T}_{2}{ }^{*}$ values of L1-L4 vertebrae did not show statistically significant differences between the study groups. $\mathrm{T}_{2}{ }^{*}$ measurements of the study groups are demonstrated in Table III. 

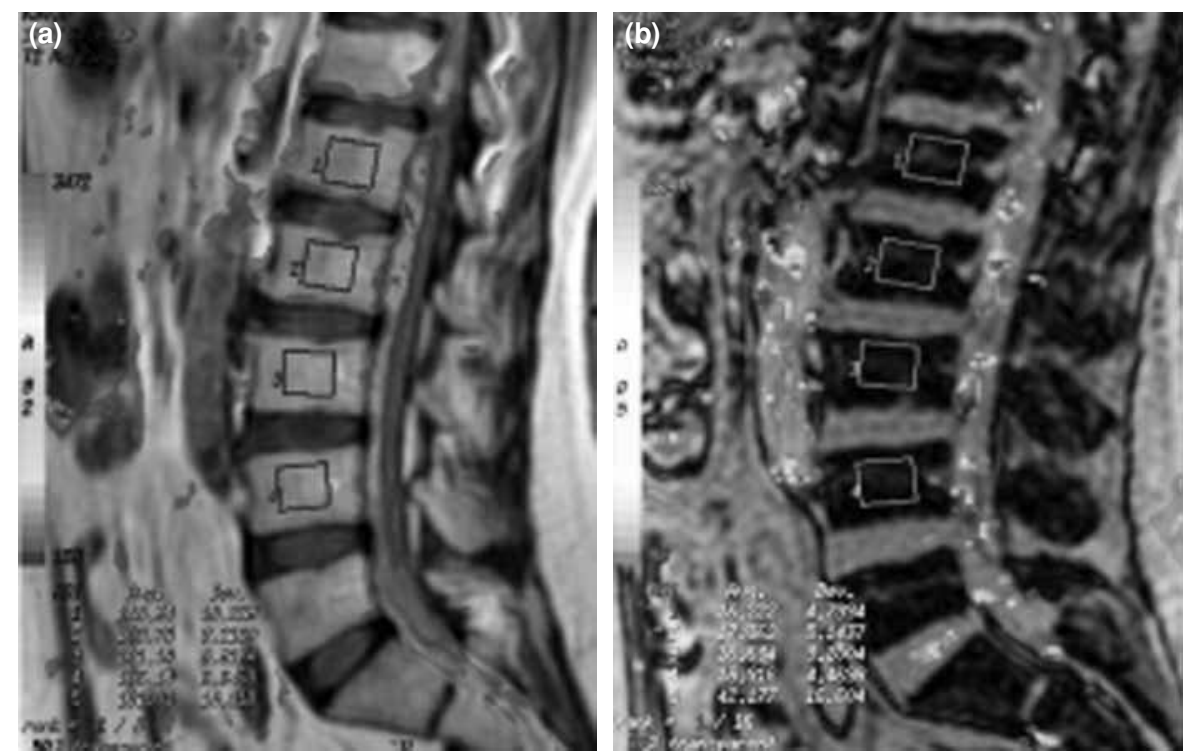

Figure 1. (a) $\mathrm{On} \mathrm{T}_{2}$ and (b) $\mathrm{T}_{2}{ }^{*}$ mappings of quantitative magnetic resonance imaging; region of interest is placed in the central portions of L1-L4 vertebral body on midsagittal images. The mean signal intensity of the region of interest is measured for each vertebra.

\section{DISCUSSION}

Osteoporosis is a clinical entity that not only has decreased bone mass, but also microarchitectural deterioration. ${ }^{[1,2,9]}$ The diagnosis of osteoporosis is crucially important as it is associated with high risk of bone fracture. ${ }^{[10]}$

Although DXA is the only reference method in osteoporosis accepted by $\mathrm{WHO}$, the fracture risk

\section{TABLE I}

The demographic features of the patients

\begin{tabular}{lccc}
\hline Patient groups & $\mathrm{n}$ & Age & BMl \\
\hline Normal & 32 & $57.2 \pm 7.7^{*}$ & $30.6 \pm 4.1$ \\
Osteopenic & 30 & $59.6 \pm 9.9$ & $29.4 \pm 5.3$ \\
Osteoporotic & 23 & $63.4 \pm 7.8^{*}$ & $30.6 \pm 5.2$ \\
\hline
\end{tabular}

BMI: Body mass index; * Statistical difference was found between the normal and osteoporotic groups $(p<0.05)$

\section{TABLE II}

$\mathrm{T}_{2}$ measurements of the study groups

\begin{tabular}{|c|c|c|c|}
\hline \multirow[t]{2}{*}{$\mathrm{T}_{2}$ value } & Normal & Osteopenic & Osteoporotic \\
\hline & Mean $\pm S D$ & Mean $\pm S D$ & Mean $\pm S D$ \\
\hline L1 & $105.5 \pm 24.5^{\star}$ & $109.2 \pm 31.9 \dagger$ & $120.7 \pm 25.9^{*}, \dagger$ \\
\hline L2 & $106.8 \pm 22.2^{*}$ & $109.6 \pm 23.4 \dagger$ & $123.7 \pm 21.6^{*}, \dagger$ \\
\hline L3 & $106.1 \pm 23.5^{\star}$ & $110.9 \pm 32.8 \dagger$ & $122.4 \pm 32.3^{\star}, \dagger$ \\
\hline L4 & $107.9 \pm 22.7^{\star}, \ddagger$ & $111.7 \pm 27.1 \dagger$,‡ & $125.0 \pm 24.1^{*}, \dagger$ \\
\hline
\end{tabular}

depends not only on BMD values, but also on qualitative and architectural changes in bone with aging. ${ }^{[2,5,11]}$ Besides the advantage of being a non-ionizing radiation technique, in recent years, MRI was introduced as an effective imaging method for assessment of bone architecture. ${ }^{[3,7,8]}$ Magnetic resonance imaging can be used to evaluate the trabecular network in two different ways. The first one is high resolution MRI (hrMRI) which enables direct visualization of the bone trabeculae. ${ }^{[12,13]}$ The second one is MR relaxometry or QMRI which proves indirect measurement of structures of bone trabeculae. ${ }^{[14]}$ As hrMRI necessitates advanced MR devices equipped with dedicated hardware and is also time consuming, its routine clinical usage is not practical. In contrast, QMRI can be performed on conventional MR devices and demands less evaluation time compared to hrMRI.

As the trabeculae alter the bone marrow signal features proportional to trabecular bone density,

TABLE III

$\mathrm{T}_{2}{ }^{*}$ measurements of the study groups

\begin{tabular}{|c|c|c|c|}
\hline \multirow[t]{2}{*}{$\mathrm{T}_{2}{ }^{*}$ value } & Normal & Osteopenic & Osteoporotic \\
\hline & Mean $\pm S D$ & Mean $\pm S D$ & Mean $\pm S D$ \\
\hline L1 & $19.0 \pm 13.5^{\star}$ & $16.0 \pm 13.9^{*}$ & $17.3 \pm 10.9^{*}$ \\
\hline L2 & $18,9 \pm 11.7^{*}$ & $17.1 \pm 14.6^{*}$ & $18.3 \pm 11.6^{*}$ \\
\hline L3 & $19.0 \pm 12.2^{*}$ & $17.1 \pm 11.8^{*}$ & $19.0 \pm 12.3^{*}$ \\
\hline L4 & $18.7 \pm 14.9^{*}$ & $17.8 \pm 15.1^{*}$ & $21.1 \pm 14.1^{*}$ \\
\hline
\end{tabular}

SD: Standard deviation; * No statistical differences were found between the study groups ( $\mathrm{p} \geq 0.05$ ). 
QMRI measuring $\mathrm{T}_{2}$ and $\mathrm{T}_{2}{ }^{*}$ signal intensity of bone marrow has been reported to be directly proportional to trabecular bone density. ${ }^{[3,8,14-16]}$ The difference in the magnetic properties of the trabecular network and bone marrow generates spatial inhomogeneity in the magnetic field and causes decreased $\mathrm{T}_{2}$ and $\mathrm{T}_{2}{ }^{*} \mathrm{MR}$ signals. ${ }^{[8,15]}$ In osteoporosis, there is a decrease in trabecular network, and QMRI studies demonstrated increased $\mathrm{T}_{2}$ and $\mathrm{T}_{2}{ }^{*} \mathrm{MR}$ signals in this disease. ${ }^{[3,7,8,15-17]}$

We found similar findings with the literature that $T_{2}$ values of L1-L4 vertebrae were increased in osteoporotic patients comparing both normal and osteopenic patients. In our study, the ages of the patients in normal and osteoporotic groups were different. In a MRI study by Dooms et al., ${ }^{[18]} \mathrm{T}_{2}$ measurements of lumbar vertebra in women were not found to be statistically different comparing fourth and fifth decades. Therefore, we supposed that statistical differences between the ages of normal and osteoporotic groups would not have altered the results.

It is reported that over half of bone fractures in postmenopausal period arise in osteopenic women. ${ }^{[19]}$ Consequently, the diagnosis of osteopenia in the postmenopausal period is very important. Although Wehrli et al. ${ }^{[20]}$ found different lumbar $\mathrm{T}_{2}$ values in normal, osteopenic, and osteoporotic patients, we could not find any statistical difference in $T_{2}$ values comparing normal and osteopenic groups while noting different $T_{2}$ values in normal and osteoporotic patients.

In contrast to reported studies, we did not find significantly different $T_{2}{ }^{*}$ values between the study groups. ${ }^{[7,8,15-17]}$ The study by Brismar, ${ }^{[7]}$ also supported our findings, and explained this result by several factors in spinal MRI. In the lumbar spine, individual differences in amounts of yellow and red bone marrow might affect the signal. ${ }^{[7]}$ Respiration artifacts on lumbar MRI can also cause vertebral $\mathrm{T}_{2}{ }^{*}$ signal intensity changes. ${ }^{[7]}$ As a result, we did not find lumbar $\mathrm{T}_{2}{ }^{*}$ measurements helpful in evaluation of osteoporosis.

Our study has a limitation in that we used DXA as a gold standard in BMD measurements. However, DXA is assumed to be a less sensitive method to measure BMD.${ }^{[9]}$ Our study has several advantages. Our study groups consisted of women. It is well known that fatty marrow content is different in women and men. ${ }^{[18]}$ If we had studied both women and men, the signal intensity measurements of the groups would not have been compared reliably. The other advantage is that we standardized the study groups according to BMI as it might also change the signal intensity measurements on QMRI.
In conclusion, $\mathrm{T}_{2}$ measurements of lumbar vertebra on QMRI may be useful in assessment of bone trabeculae in osteoporosis, and may also be helpful to differentiate osteoporotic from normal, and osteopenic from osteoporotic patients.

\section{Acknowledgement}

We highly appreciate the technical support by Ercan Carmikli, who works as MRI technician in Gazi University Department of Radiology.

\section{Declaration of conflicting interests}

The authors declared no conflicts of interest with respect to the authorship and/or publication of this article.

\section{Funding}

The authors received no financial support for the research and/or authorship of this article.

\section{REFERENCES}

1. Link TM. Osteoporosis imaging: state of the art and advanced imaging. Radiology 2012;263:3-17. doi: 10.1148/ radiol.12110462.

2. Atik OS. Is DXA the gold standard? [Article in English, Turkish] Eklem Hastalik Cerrahisi 2011;22:63.

3. Akyol Y, Alaylı G, Diren B, Cengiz K, Canturk F. Assessment of trabecular bone structure with magnetic resonance T2 relaxation time in osteoporosis. Turk J Phys Med Rehab 2008;54:50-3.

4. Brunader R, Shelton DK. Radiologic bone assessment in the evaluation of osteoporosis. Am Fam Physician 2002;65:1357-64.

5. Cummings SR, Nevitt MC, Browner WS, Stone K, Fox KM, Ensrud KE, et al. Risk factors for hip fracture in white women. Study of Osteoporotic Fractures Research Group. N Engl J Med 1995;332:767-73.

6. Atik OS. FRAX ${ }^{\mathrm{TM}}$ and Turkey (Osteoporotic fracture risk assessment). Eklem Hastalik Cerrahisi 2008;19:100.

7. Brismar TB. MR relaxometry of lumbar spine, hip, and calcaneus in healthy premenopausal women: relationship with dual energy X-ray absorptiometry and quantitative ultrasound. Eur Radiol 2000;10:1215-21.

8. Link TM, Majumdar S, Augat P, Lin JC, Newitt D, Lane NE, et al. Proximal femur: assessment for osteoporosis with $\mathrm{T} 2 *$ decay characteristics at MR imaging. Radiology 1998;209:531-6.

9. Gül O, Atik OS, Erdoğan D, Göktaş G. Is bone microstructure different between osteopenic and osteoporotic patients with femoral neck fracture?. [Article in Turkish] Eklem Hastalik Cerrahisi 2012;23:15-9.

10. Eren OT, Küçükkaya M, Balcı V, Kabukçuoğlu Y, Kuzgun Ü. Radius distal uç kırıklı hastalarda kemik mineral yoğunluğu ölçümü. Eklem Hastalik Cerrahisi 2003;14:158-63.

11. Hatipoglu HG, Selvi A, Ciliz D, Yuksel E. Quantitative and diffusion MR imaging as a new method to assess osteoporosis. AJNR Am J Neuroradiol 2007;28:1934-7.

12. Newitt DC, Majumdar $S$, van Rietbergen $B$, von Ingersleben G, Harris ST, Genant HK, et al. In vivo assessment of architecture and micro-finite element analysis derived 
indices of mechanical properties of trabecular bone in the radius. Osteoporos Int 2002;13:6-17.

13. Link TM, Majumdar S, Augat P, Lin JC, Newitt D, Lu Y, et al. In vivo high resolution MRI of the calcaneus: differences in trabecular structure in osteoporosis patients. J Bone Miner Res 1998;13:1175-82.

14. Maris TG, Damilakis J, Sideri L, Deimling M, Papadokostakis G, Papakonstantinou O, et al. Assessment of the skeletal status by MR relaxometry techniques of the lumbar spine: comparison with dual X-ray absorptiometry. Eur J Radiol 2004;50:245-56.

15. Sebag GH, Moore SG. Effect of trabecular bone on the appearance of marrow in gradient-echo imaging of the appendicular skeleton. Radiology 1990;174:855-9.

16. Grampp S, Majumdar S, Jergas M, Newitt D, Lang P, Genant HK. Distal radius: in vivo assessment with quantitative
MR imaging, peripheral quantitative CT, and dual X-ray absorptiometry. Radiology 1996;198:213-8.

17. Wehrli FW, Ford JC, Haddad JG. Osteoporosis: clinical assessment with quantitative MR imaging in diagnosis. Radiology 1995;196:631-41.

18. Dooms GC, Fisher MR, Hricak H, Richardson M, Crooks LE, Genant HK. Bone marrow imaging: magnetic resonance studies related to age and sex. Radiology 1985;155:429-32.

19. Pasco JA, Seeman E, Henry MJ, Merriman EN, Nicholson GC, Kotowicz MA. The population burden of fractures originates in women with osteopenia, not osteoporosis. Osteoporos Int 2006;17:1404-9.

20. Wehrli FW, Hopkins JA, Hwang SN, Song HK, Snyder PJ, Haddad JG. Cross-sectional study of osteopenia with quantitative MR imaging and bone densitometry. Radiology 2000;217:527-38. 